\title{
The Sensitivity of Financial Position and Financial Behavior of Young Workers
}

\author{
Mila Arlinawati, Ni Nyoman Sawitri, and Kabul Wahyu Utomo \\ Fakultas Ekonomi dan Bisnis, Universitas Trilogi, Indonesia \\ Email: sawitri@trilogi.ac.id
}

\begin{abstract}
The phenomenon of financial behavior from young workers in Indonesia is important to be studied; it relates to the financial position in the future. Reviewing for the phenomenon, so this research focuses on the impact of financial behavior on financial position supported by financial ability, locus of control, financial knowledge, financial attitude, income, and individual ethnicity. This experimental study is conducted on young workers in Jakarta (Indonesia), it is about 132 young workers taken data through questionnaires. The analysis technique used by path analysis with Smart PLS tools. The research finding is found that financial behavior does not always determine the financial position of young workers. Many other cases can determine financial position directly are financial knowledge and the ethnicity of young workers. While financial behavior can be truly created by the support of financial ability, financial attitude, and income.
\end{abstract}

Keywords: Financial Behavior, Financial Position, Financial Ability, Financial Attitude, Ethnicity.

\begin{abstract}
Abstrak: Fenomena atas perilaku keuangan dari pekerja muda di Indonesia penting untuk dikaji berkaitan dengan posisi keuangan masa mendatang. Menelaah atas fenomena maka kajian penelitian ini fokus pada dampak perilaku keuangan pada posisi keuangan yang didukung oleh kemampuan keuangan, kontrol diri, pengetahuan keuangan, sikap keuangan, pendapatan dan etnis individu. Penelitian eksperimen ini dilakukan pada pekerja muda di Jakarta (Indonesia), sebanyak 132 pekerja muda diambil datanya melalui kuesioner. Tehnik analisis yang dilakukan melalui analisis jalur dengan alat bantu SmartPLS. Hasil penelitian ditemukan bahwa perilaku keuangan tidak selalu menentukan posisi keuangan pekerja muda. Banyak hal lain yang mampu menentukan posisi keuangan secara langsung yaitu pengetahuan keuangan, dan etnis dari pekerja muda. Sedangkan untuk perilaku keuangan sejatinya dapat tercipta dengan dukungan dari kemampuan keuangan, sikap keuangan, dan pendapatan.
\end{abstract}

Kata Kunci: Perilaku Keuangan, Posisi Keuangan, Kemampuan Keuangan, Sikap Keuangan, Etnis.

\section{INTRODUCTION}

Financial management is no longer intended for financial institutions and the business community, but it is also used to manage someone's financial management (Gadenne et al., 2012). Because in someone's activities, it is related to finance, both to support primary or secondary needs (Barakat, 2014). Everyone certainly requires financial planning so that 
income and financial expenses following the initial goal planned. This applies mostly to young workers, who only have their income and plan for every income in the form of finances used for daily life is fulfilling monthly (Alamsyah et al., 2018). Every individual has goals to be achieved in his life to determine the future (Keh and Xie, 2009). It needs to be supported well by one of the determinants factors, which is financial management so that future goals can be achieved (Gadenne et al., 2012). However, it is sometimes uncommon that many future goals are not achieved because miscalculations in financial management, so it is very important to notice to financial management, particularly in young workers. It explains the importance of financial management for young workers to be able to support financial positions in the future.

The financial position of workers reflects the number of wealth owned at a certain time; the wealth is achieved in financial management which is carried out monthly (Sawarjuwono, 2003). Financial management occurs when all of the inflows and outflows of workers' finances are determined before (Shiamwama et al., 2014), with the ultimate goal of achieving a more favorable financial position. However, the goals are achieved by each worker must be different as well as in the process of achieving it. Some individuals plan for the future in detail, directed and matured, but some of them are without any planning at all (Henager and Cude, 2016). Workers who know and apply financial management are wiser in using funds and they realize how to manage financial management to be healthier. The previous studies have revealed that young-age is a transition from childhood to adulthood, so it is important for them to learn and to regulate their needs and intentions, to understand future investments (Pension et al., 2018). Examining from this theory which explains the importance of young workers, starting to implement financial management early for a better future; the measurement is obviously through the financial position of young workers. It is needed a financial literacy education about how to save and loan.

The financial position makes workers can understand time well; thus career development and life go well (Banerjee et al., 2016; Sawitri and Astuty, 2018). Understanding financial position means that workers know all of the assets owned, all of the accounts payable and financial estimates that will roll every month as income (Dwiastanti, 2017). It means that financial position is all information which is the amount of investment owned by workers at a time unit (Pension et al., 2018). By knowing the financial position, each individual can provide more appropriate economic decisions (Dwiastanti, 2017). Thus, explaining the importance of the financial position to support every decision that has an impact on someone's economy. The financial position of an individual is surely determined by three things, namely the level of individual education, individual mentality behavior and social factors of individuals (Denny and Steiner, 2009). This behavior provides an impact on the management of individual financial management, so it is often a determinant of individual financial management patterns (Banerjee et al., 2016). However, there is rarely for young workers who are less aware of the importance of financial management as it happens in Indonesia. It appears from the number of expenses rather than income, and it is often trapped in the condition that the greater of income so the greater of expense (Wahyudi and Sani, 2014). This behavior provides an adverse effect, where assets are unclear until the financial position is unclear too. There are not a few young workers in Indonesia have already a good education, and they do not have a high life demands because of the support of parents (Rizvi and Arshad, 2016). It becomes interesting 
to be studied as a research object about the importance of financial positions in young workers.

The basic of financial position is financial behavior; in which the individual character in carrying out economic principles in daily life (Wang et al., 2011). In financial behavior, each individual is responsible for all financial decisions (Košak et al., 2015). Older workers tend to be more careful in financial behavior, because of the impact of financial behavior on the family's financial position (Louati et al., 2015). It is different from young workers, who do not have demands on family, so it is often for financial behavior not accompanied by the economic principle which is balancing between income and expense (Sawitri et al., 2019; Wang et al., 2011). Current financial behavior is widely studied in Indonesia, it is examined that consumption patterns of Indonesian people have mostly short-term consumption behavior and it does not consider to consumption behavior in long term, it has an impact on financial position (Wahyudi and Sani, 2014).

Examining the phenomenon of financial behavior, it is important to study more closely related to financial position, particularly for young workers. The basic of financial behavior is financial capability possessed by someone, the higher of financial capability, the more variety of financial behaviors arise (Xiao and Porto, 2016). Today, young workers tend to use their money only for personal needs and they rarely think of investing. Young workers have an assumption that investment is identical for adults who think for the future (Wahyudi and Sani, 2014). This is evidenced by the number of investments circulating in one company which is more dominated by experienced or older workers (Lee et al., 2013). Young workers need to think about investment early because it is still in a productive period, and the results will be received more quickly in the future. Another thing that does not support financial behavior for investment in young workers is that the financial capability of young workers is dominated by standard financial capabilities, remember that they have started to work or business (Henager and Cude, 2016). So, it is assumed commonly if a few have thought in the investment field for the future. In the practice of financial management, it is known that an individual's financial behavior depends on three things, which are consumption patterns, the number of assets owned and future savings (Wilmarth, 2017). However, these three things are dependent on financial capability finally, because a large or small financial capability determines individuals' character, especially for young workers in behaving their financial management (Garg and Singh, 2018; Sawitri, 2019).

In previous studies, it is known that there is individuals' behavior in finance which can change someone's personality about finance, which is the locus of control (Gomezelj and Kušce, 2013). Relating to the locus of control helps each individual in implementing the principles of financial management, namely effective and efficient (Ritchie \& Brindley, 2009). With the final results, supporting financial behavior that impacts the financial position of individuals (Gomezelj and Kušce, 2013). Locus of control is needed by every individual, particularly in young workers who still have not much experience in financial management. Because the locus of control provides the best provision for young workers in carrying out better financial behavior. Furthermore, in the financial decision process, locus of control is a behavior that can support individuals in refraining from shopping based on intention, not necessities (Ritchie and Brindley, 2009). Because the locus of control is truly needed by young workers in dealing with impulsive or compulsive buying behavior (Meyer et al., 2002). In financial behavior, locus of control depends on the process of selfmonitoring of all financial activities, if it fails then the locus of control cannot occur. The 
difficulty of young workers in the locus of control is due to the current earn of modernization, where all of someone's needs can be easily fulfilled. Where almost all types of goods and services become very easy to obtain. The importance of young workers in controlling themselves is related to financial management, because of its impact on financial behavior and financial position (Chen and Chang, 2013).

Every individual is behaving either in purchasing behavior or financial behavior are depending on the level of knowledge possessed by an individual (Arianti, 2017; Hariyanto and Alamsyah, 2019). It is the same case with customers' purchasing behavior, it is truly more influenced by customers' knowledge of product purchased (Chen and Chang, 2013). Likewise, with financial behavior, many of them are controlled by knowledge of finance, financial knowledge is obtained from studies during education or it is based on experience carrying out financial activities (Dwiastanti, 2017). However, more financial knowledge can be implemented based on financial experience (Kadoya and Khan, 2017). It often happens obviously to experienced workers than young workers. Though financial knowledge is very important related to the financial behavior of each individual (Rehman et al., 2019). The essence of financial knowledge research, so it is needed the education of financial management, particularly in young workers, to support better financial behavior. Although financial knowledge has been known by young workers during the previous studies at school or college.

Financial knowledge is often associated with financial attitudes (Wong et al., 2018) because every individual who has a good knowledge of financial management has a good attitude towards financial matters. Although both of them have different understandings, where financial knowledge is more prioritizing a behavior in the state of thinking; timing and valuing about finance (Henager and Cude, 2016). It is different from the financial attitude which is related to the implementation of financial management. Individuals are considered to have financial attitudes if the implementation of financial management has been pre-arranged (Arianti, 2017). Thus, supporting financial behavior and providing a great opportunity for individuals to achieve better financial positions. Financial attitudes to young workers are often disrupted by the level of economic maturity and the maturity of financial knowledge so that there are not a few financial attitudes that prioritizing the intention of young workers' needs. Therefore, the importance of controlling financial attitudes for young workers, if it relates to the future of financial positions. Financial attitude is a mindset of individuals in behavior, financial attitude is strongly supported by the amount of income (Szendrey and Fiala, 2018). Because income is a source of financial behavior, namely financial attitude. It means that the financial behavior of young workers is depended on large or small of their income and financial attitude. However, the interesting thing about the financial behavior of young workers is based on the ethnicity of young workers (Smith, 2019). Because ethnicity is related to beliefs, values, habits, customs, and history of the individual which relates to financial management (Ansar et al., 2019). It means that an individual's financial behavior is often related to individuals' habits in his daily life with his ethnicity. Financial behavior is basic in assessing a person's financial position; many factors determine a person's behavior, but it is necessary to know the behavior can support financial position, particularly in young workers.

Reviewing the phenomenon of financial behavior to young workers are related to financial positions in the future (Moreland, 2018), this research focuses on examining the impact of financial behavior on the financial position of young workers. Financial behavior 
itself is known to be based on several characters, are financial capability, locus of control, financial knowledge, financial attitudes, income, and ethnicity. This research is important to conduct particularly to young workers in Indonesia who have different financial behaviors. Moreover, this research provides important information support for stakeholders, because it is known as the best model in assessing financial behavior which supports the financial position of workers in the future. So that it is expected to be able to support the economic growth of Indonesian people, through the study of financial behavior.

\section{THEORETICAL REVIEW}

Financial Capability. Financial literacy is reflected by someone's knowledge and cognitive abilities in finance (Wong et al., 2018). These four things are most common in financial literacy, namely knowledge, and abilities regarding budgeting, savings, loans, and investments (Xiao and Porto, 2016). Financial knowledge helps individuals in providing an understanding of managing finances and opportunities to achieve a more prosperous life in the future (Wong et al., 2018). So that financial knowledge is closely related to financial management, where the higher level of individual financial literacy, the better financial management of the individual. Personal financial management is one application of financial management concepts at the individual level (Wilmarth, 2017).

The financial capability of the individual truly reflects how far the individuals understand financial knowledge (Szendrey and Fiala, 2018). In theory, financial capability is stated as knowledge, skills, and beliefs, which influence attitudes and behaviors to improve the quality of decision making and financial management to prosper (Henager and Cude, 2016). This opinion explains the ability of finance as knowledge achieved by the individual in managing their finances. Other opinions explain the point of view related to financial ability about how someone's ability to process the economic information obtained and make the decision to make financial planning, financial accumulation, pensions and debt (Wilmarth, 2017). Financial capability is truly assessed from several indicators, which is smart handling in financial problems, recording monthly expenses, spending more than income, being able to manage finances and to meet needs with the ability (Henager and Cude, 2016). In the most recent research studies, it has been known that an individuals' financial capability has a relationship both with financial behavior (Wilmarth, 2017) and with someone's financial position (Moreland, 2018), reviewing from that theories so it is determined for research hypothesis as follows:

H1: There is a positive correlation between financial capability in financial behavior.

H2: There is a positive correlation of financial capability in financial position.

Locus of Control. It is a behavior that drives individuals with the belief that if they work hard, they will succeed and believe that people who fail are due to lack of ability or motivation (Meijers et al., 2013). Individuals who have a locus of control are identified more relying on self-expectations and it is identified also to choose skills than one favorable situation (Zainol, 2011). The results achieved from the locus of control are described to his activities. For someone who has the locus of control will see the world as something that can be predicted, and individual behavior also plays a role inside of it (Meijers et al., 2013). 
The concepts of locus of control were firstly proposed by Rotter in 1966, relating to the science of personality. The development of locus of control is also related to individual behavior in financial management (Dwiastanti, 2017). Where locus of control is stated to be one of the personality variables or individual confidence in being able to control someone's destiny (Arianti, 2017).

Assessing locus of control depends on the individual's internal behavior (Begley and Boyd, 1987), it means that locus of control is more influenced by behaviors related to selfattitude. It is known that in previous studies related to self-attitude in financial management can be assessed through several indicators including to be able to realize intentions, everything that happens depending on yourself, it has control for events happened and it can face problems (Dwiastanti, 2017; Hikmawati and Alamsyah, 2018). Furthermore, in previous studies it was known that the correlation of locus of control in financial management is related to financial behavior (Arianti, 2017) and financial position (Dwiastanti, 2017), examining the phenomenon, the hypothesis in this study is determined as follows:

H3: There is a positive correlation of locus of control in financial behavior.

H4: There is a positive correlation of locus of control in financial position.

Financial Knowledge. In financial behavior, it is known as financial knowledge, which is developed by every individual in financial management (Di Benedetto and Kim, 2016). To develop financial behavior, individuals must have financial knowledge so that each financial decision is suitable personally beneficial (Croy et al., 2010). Financial knowledge is the key to the understanding of personal finance and ideas which are needed and useful for the surrounding community (Sydler et al., 2014). Financial knowledge is very extended, it is usually related to banking, savings, insurance, the use of credit, taxes, and investment (Totenhagen et al., 2019). Every individual is required to have basic financial knowledge, but not at all need to be applied but it is adjusted to their needs. The higher financial knowledge is truly better in individual financial management (Wong et al., 2018).

Financial knowledge depends on how deep the knowledge possessed; where financial knowledge is everything about the finance that is experienced or it occurs in the daily life of individuals (Henager and Cude, 2016). Another theory explains that financial knowledge is everything about the finance that is experienced or it happens in everyday life (Totenhagen et al., 2019). In practice, individuals have financial knowledge when the individual's mastery of financial tools and financial skills (Moreland, 2018). Financial knowledge can be assessed from several behaviors in each individual, including judging from knowing bank and loan interest rates, knowing managing personal finances, knowing how to invest money, and knowing bank statements (Totenhagen et al., 2019). It appears that all these measurements can be used as measurements in financial knowledge because they relate to financial management. Furthermore, it is also known from previous research in financial behavior (Moreland, 2018) and someone's financial position (Shivam and Kumar, 2017). The essence of these findings is used as the purpose of this study with the following hypothesis design:

H5: There is a positive correlation between financial knowledge in financial behavior. 
H6: There is a correlation between financial knowledge in financial position.

Financial Attitude. In theory, it is explained that it relates to individual attitudes in good behavior daily in financial management, it always based on knowledge or experience before (Ghosh, 2014). Attitudes will strengthen the way someone thinks about something finally. Furthermore, attitude relates to the way of thinking about someone's finance; it is termed as financial attitudes (Murray and Vogel, 1997). It has been said that financial attitudes are states of mind, opinions, and judgments about the finance of every individual (GoeddeMenke et al., 2014). So, it can be investigated that financial attitudes have an impact on someone's financial behavior in their activities. Financial attitude has an important role in determining the success or failure of a person's financial behavior (Wong et al., 2018). The higher the financial attitude of someone, the higher awareness to be responsible for the use of finances, so that it will have a positive impact on financial behavior. In financial behavioral science, financial attitude is considered as a perception of the importance of conducting activities related to finance (Shivam and Kumar, 2017). Examining from the previous studies explains that the importance of financial attitudes towards the state of mind, opinions, and judgments about personal finances (Arslan et al., 2013).

Concerning financial attitudes, it has been found that several evaluation indicators which determine are responsible for his financial prosperity, saving is important, it is more concentrating in managing finances, making financial plans for retirement, making financial plans, developing regular savings patterns, writing financial goals for setting priorities, a written budget is very important, and planning is important for financial success (Wong et al., 2018). Furthermore, it has been examined that financial attitude of individuals can influence financial behavior (Shivam and Kumar, 2017) and financial position (Dwiastanti, 2017) so that the analysis of these opinions in this study is determined by research hypothesis as follows:

H7: There is a positive correlation between financial attitudes in financial behavior.

H8: There is a positive correlation between financial attitudes in the financial position.

Income. Large or small of a person's income, it depends on the level of work performed by each individual (Fauceglia, 2014). Income is the total real income of all household members who are donated to meet the necessities of households and individuals in the household (Moradi et al., 2016). For young workers, income is received to be used to fulfill their needs. The initial theory is stated to be related to income that income comes from main or side jobs, in the form of salary, rent or in other forms to fulfill needs and intentions that make you happier (Arianti, 2017). The theory explains that the amount of income depends on the amount of work risk. Another opinion explains that an individual's income is the total annual gross income of an individual from wages, business enterprises and various investments (Kadoya and Khan, 2017). Also, there are many other categories of income including rental income, payment of government subsidies, interest income and dividend income (Dwiastanti, 2017). In practice, income is always associated with financial behavior because all good and right financial decision is needed to increase revenue, managing expenses, and paying taxes to financial management becomes good. 
Descriptive studies relate to individual opinions; it depends on several measurements such as if getting income whether it saves, following a monthly or weekly budget, saving money obtained for retirement and managing emergency savings funds from income (Xiao and Porto, 2016). Through several questions on income, it can determine descriptively the amount of individual income. Besides that, an individual's income, in this case, is workers, have been known to have links with financial behavior (Xiao \& Porto, 2016) and individual financial position (Rehman et al., 2019). Examining the theory of current income and financial behavior, the next research hypothesis design is as follows:

H9: There is a positive correlation between income in financial behavior.

H10: There is a positive correlation between income in financial position.

Ethnicity. Every individual in financial behavior is always associated with the culture embraced and trusted (Smith, 2019). Sometimes, the knowledge of finance does not always act to influence financial behavior when there is a pressure of dominant individual culture (Ansar et al., 2019). Individual culture is attached to and entered into the ethnic area of the individual, the greater of ethnicity adjusted by the individual, it greatly determines the financial behavior of individuals (Subramaniam et al., 2014). Because ethnicity is also related to the level of the individual ego in behavior (Meijers et al., 2013). In theory, ethnicity is said to be a classification of people based on beliefs, values, habits, customs, language norms, history, geography, and kinship relations (Smith, 2019). Ethnic refers to people who are based on origins as the cultural heritage of certain groups of people (Subramaniam et al., 2014). Sociologists often use the term "ethnic group" to any form of group, it is socially assumed to exist and it has developed its subculture (Ritchie and Brindley, 2009). In other words, an ethnic group is a group recognized by the community and by the ethnic group itself as a separate group.

The ethnicity or culture of a person is brought from childhood to influence the way to manage finances in individuals and families (Smith, 2019). Financial management is closely related to financial planning. Financial planning is the process to achieve short-term and long-term financial goals (Arianti, 2017). Regarding the impact of ethnicity, it is known that several measurements are often used, which is culture influences to financial behavior, culture influences to quality of life, culture influences to criteria for determining the type of investment, the environmental impact following financial criteria (Ansar et al., 2019). From the previous research studies, it is known that a person's ethnic value determines to the development of financial behavior (Smith, 2019) and financial position (Ansar et al., 2019), the theory becomes the current research adaptation and here is the hypothesis as follows:

H11: There is a positive correlation between ethnicity in financial behavior.

H12: There is a positive correlation between ethnicity in financial position.

Financial Behavior and Position. Financial behavior is often associated with the financial position because the impact of financial behavior often determines someone's financial position (Wilmarth, 2017). Many studies have been conducted in financial behavior (Wong et al., 2018), but it very rarely explains the significant impact of financial behavior in 
financial position. Because many factors determine a person's financial position. Financial management behavior leads to an individual's way to manage their sources of funds to be used as a decision in the use of funds, determining the source of funds, as well as the decision to make a retirement planning (Henager and Cude, 2016). In the management process, it is not easy to apply because there are several steps must be followed (Wong et al., 2018). By knowing the basics of financial management, the individual will know that everything must be considered at first before making a decision (Wilmarth, 2017). In theory, it is explained that financial behavior is a person's ability to manage (planning, budgeting, examining, managing, controlling, searching and storing) daily financial funds (Kadoya and Khan, 2017). In practice, management of financial behavior is divided into three main things namely consumption, savings and investment (Dwiastanti, 2017). Relating to financial behavior, it seems clear about how money saved is used for the long term.

Besides financial behavior that is attached in an individual, there is a financial position too in the end (Szendrey and Fiala, 2018). In theory, it is said that financial position is a picture of an individual's financial situation which is indicated by the value of wealth and debt owned (Moreland, 2018). In assessing an individual's financial position, descriptive indicators are needed, such as relating to the question about not having enough money, not being able to buy a primary needs, being unable to pay for utilities, not being able to buy secondary needs, not paying bills, spending more than money possessed, cutting living cost and have financial problems (Kadoya and Khan, 2017). The study of financial position is often related to financial behavior, it is added by previous studies that explain the correlation between financial behavior in determining someone's financial position (Totenhagen et al., 2019). Accepting the explanation, the research also determines the hypothesis of the financial position as follows.

H13: There is a positive correlation between financial behavior in financial position.

According to the theory of financial behavior and financial position are supported by financial capability, locus of control, financial knowledge, income, and ethnicity, so it is analyzed and found thirteen of hypotheses design. Those designs are examined through a model illustrated in Figure 1.

Figure 1. Research Hypothesis Model

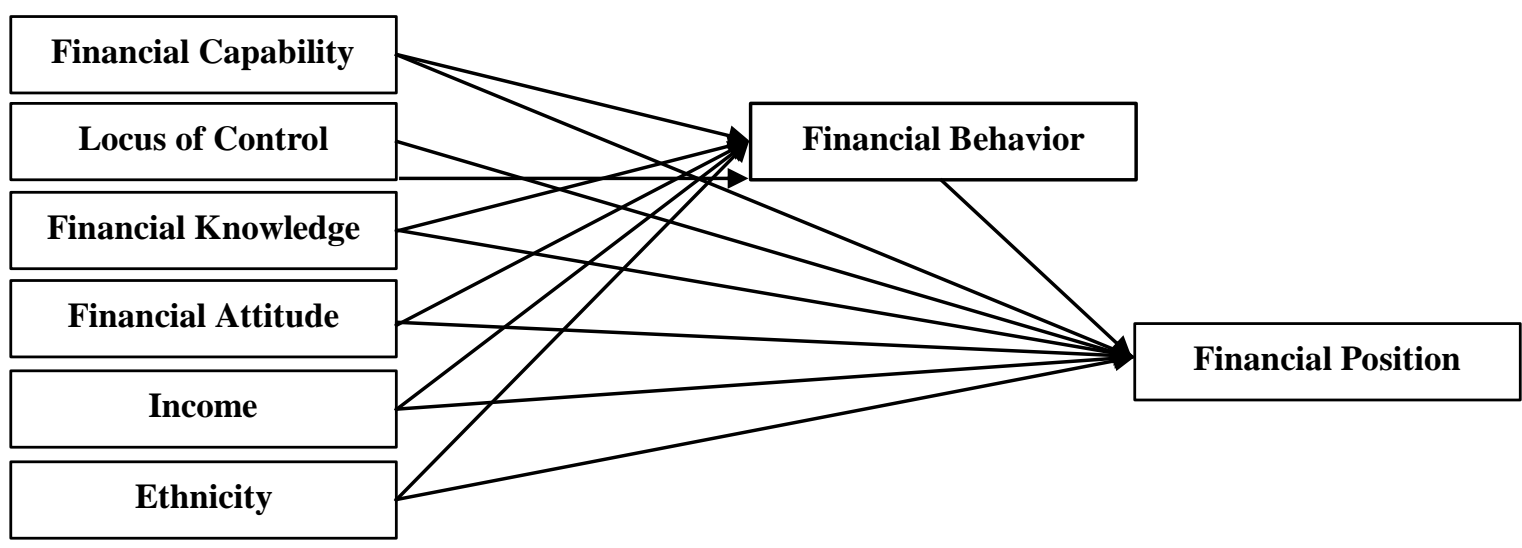




\section{METHODOLOGY}

Method and Research Object. This research focused on reviewing the correlation among variables with the main objective was studying the correlation of financial behavior to financial position. Then, this research was experimental research with the method of the survey to young workers in the Jakarta area, considering Jakarta was the Capital city of Indonesia as the center of the state's economy and it had a variety of young workers. Data from the respondent was determined to 150 young workers and data obtained through spreading questionnaire that had been determined for its answer with Liker Scale approach which was the value of "1" for very disagree until "6" for very agree.

Research Measurement and Data Analysis Model. There were eight of the main variable examined in this research; each variable was measured by some indicators such as financial capability ( 5 measurements), locus of control (4 measurements), financial knowledge (4 measurements), financial attitude (9 measurements), income (4 measurements), ethnicity (4 measurements), financial behavior (1 measurement) and financial position (8 measurements). The questionnaire spread directly to young workers in Jakarta in 2019, data from questionnaire processed and did research instrument testing and research model testing. Then, the analysis tool to examine path analysis was used SmartPLS, with inner and outer model testing.

\section{THE RESULTS OF STATISTICAL TESTS}

The research result has been known that from 150 questionnaires spread, 132 respondents have valid data, namely a perfect data charging. So only 132 respondents which are processed by SmartPLS for data. First, research instrument testing is conducted by the model test to the model can be accepted through some criterion goodness-of-fit index (Hong et al., 2006). Here is known that the result of testing concluded in Table 1. The test of the goodness-of-fit index also represents the research instrument test, where all of the criteria also represent a research instrument test, where all criteria are accepted, and the study is continued by analyzing the research model.

Table 1. Results of Model Testing

\begin{tabular}{lccc}
\hline \multicolumn{1}{c}{ Criteria } & Acceptable & Result Score & Result \\
\hline Convergent Validity & $>0.50$ & Outer Loading $>0.50$ & Accepted \\
\hline Composite Reliability & $>0.70$ & Composite Reliability $>0.80$ & Accepted \\
\hline Average Variance Extracted & $>0.40$ & AVE $>0.50$ & Accepted \\
\hline Cronbach's Alpha & $>0.70$ & Cronbach's Alpha $>0.70$ & Accepted \\
\hline Outer Weight & $>2.00$ & Outer Weight $>2.00$ & Accepted \\
\hline
\end{tabular}

Source: (data processed, 2020)

After it is known the result of inner and outer model testing through the goodness-fit index, then research model testing to know the correlation value from every correlation among variables. The results of the test are illustrated in Figure 2, where it can be explained that financial ability has a positive correlation to financial behavior $(0.337)$ and a negative 
correlation to financial behavior (-0.001) and correlates positively to the financial position (0.124). After that, to financial knowledge of young workers has a negative correlation to financial behavior $(-0.310)$ and it correlates negatively to the financial position $(-0.036)$. besides that, it has been known that financial attitude has a positive correlation either to financial behavior $(0.229)$ or to the financial position $(0.050)$. it is different from the income of young workers, where it correlates only positively to financial behavior (0.446), while it correlates negatively to the financial position (-0.336). Finally, it has been known that the ethnicity value of young workers has a positive correlation either to financial behavior 90.076) or to the financial position (0.224). Knowing from various correlation values that support and not support both in financial behavior and financial position to young workers, so in research, the finding is assumed that the newest research model can be knowledge input in financial behavior and financial position of young workers in Indonesia.

Figure 2. The Correlation Value of Research Result

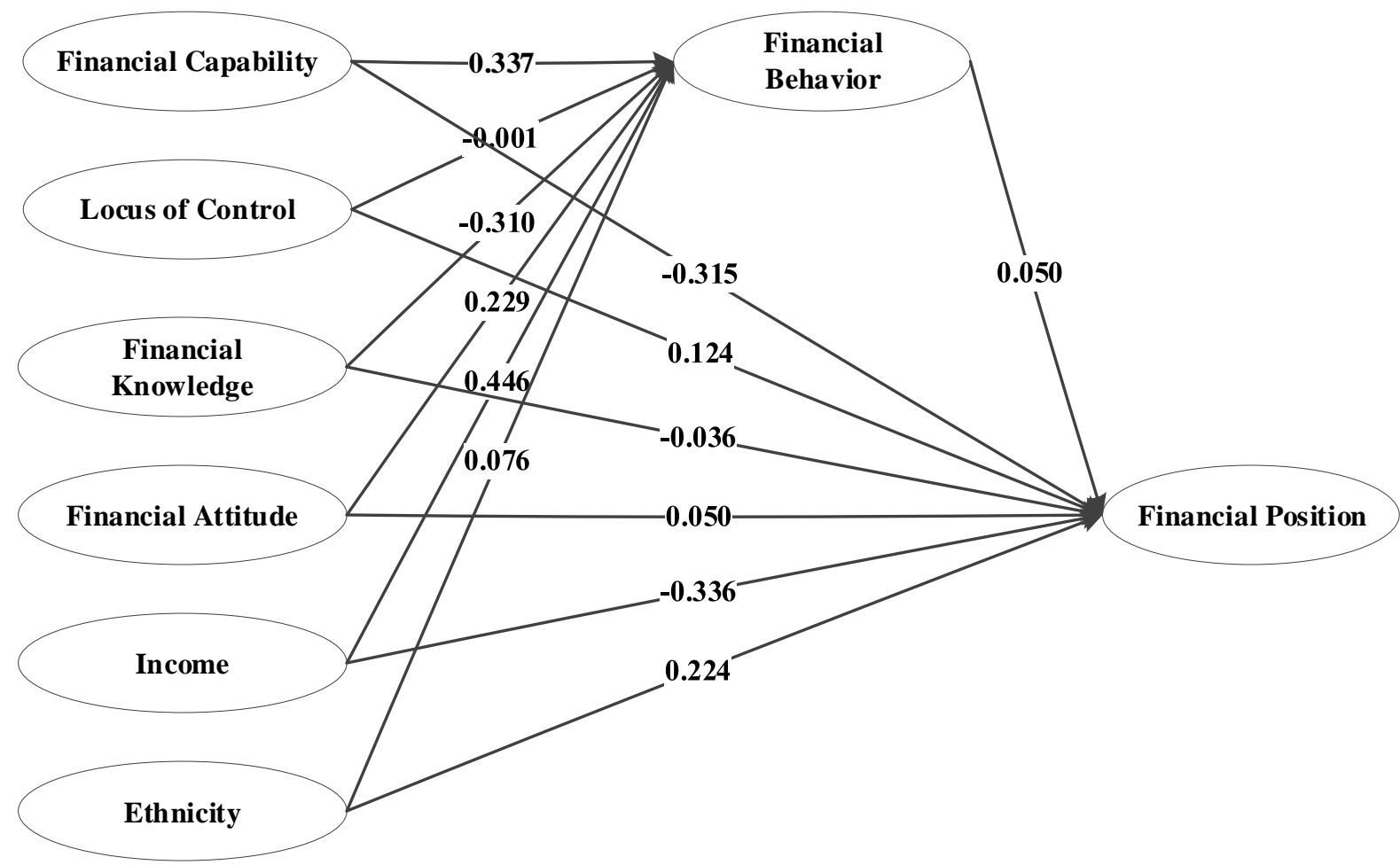

After it is known that research results based on the correlation value of each research variable, the next stage is the research hypothesis test with the criterion is receiving a research hypothesis if the value of t-statistical overs 1.986 for the significance value $\mathrm{p}<0.05$. Here is the summary of the research hypothesis test result is in Table 2. 
Table 2. Results of Research Hypothesis Test

\begin{tabular}{lcc}
\hline \multicolumn{1}{c}{ Hypothesis Design } & t-statistical & Result \\
\hline Financial Capability to Financial Behavior (H1) & 2.909 & Significant \\
\hline Financial Capability to Financial Position (H2) & 2.300 & Significant \\
\hline Locus of Control to Financial Behavior (H3) & 0.004 & Not significant \\
\hline Financial Locus of Control to Financial Position (H4) & 0.845 & Not Significant \\
\hline Financial Knowledge to Financial Behavior (H5) & 2.464 & Significant \\
\hline Financial Knowledge to Financial Position (H6) & 0.237 & Not Significant \\
\hline Financial Attitude to Financial Behavior (H7) & 2.453 & Significant \\
\hline Financial Behavior to Financial Position (H8) & 0.453 & Not Significant \\
\hline Financial Income to Financial Behavior (H9) & 4.468 & Significant \\
\hline Financial Income to Financial Position (H10) & 2.830 & Significant \\
\hline Financial Ethnicity to Financial Behavior (H1) & 0.902 & Not Significant \\
\hline Financial Ethnicity to Financial Position (H12) & 2.526 & Significant \\
\hline Financial Behavior to Financial Position (H13) & 0.453 & Not Significant \\
\hline
\end{tabular}

Source: (data processed, 2020)

\section{DISCUSSIONS}

Financial Behavior as the Impact of Ability, Attitude, and Income. The financial behavior of young workers is very determined by some factors such as financial capability, financial knowledge, financial attitude, and income. It is in line with research results that had been explained in Figure 2. However, the interesting thing about a research finding is that financial knowledge does not impact well to financial behavior of young workers. Based on research finding is known that the higher of financial knowledge, it truly does not support the creation of good financial behavior. It is caused by the unpreparedness of young workers in receiving all the financial knowledge, it seems young workers assume that there are too many theories of financial management. But there's is a few of its benefits to control financial conditions. Studying of problem facts can be explained that controlling needs to be supported by financial capability which is how big of young workers' capability to control cash flow from individual finance, it is continued by financial attitude which is the policy level of young works in managing financial, also income from young workers wich is large and small of income determines a wiser or not for their behavior.

Part of this research finding is truly in line with previous research, and there is arguing the previous research (Wilmarth, 2017) according to hypothesis test results. In hypothesis test $(\mathrm{H} 1)$ has been known that financial capability correlates with the financial behavior of young workers, it is in line with previous research and it can complete to previous research (Wilmarth, 2017). It is the same with the correlation between financial attitude (H7) and income (H9) with the financial behavior of young workers. In which the results are in line with previous research (Shivam and Kumar, 2017), and it can complete to previous research. It is different from the correlation of financial behavior to the locus of control (H3), financial knowledge (H5) and ethnicity (H11) which seems is not line with previous research studies (Arianti, 2017), it means that it argues previous research. This finding explains that locus of control does not always consist of financial expense that providing the meaning impact on 
financial behavior because the higher financial capability and income can change the financial behavior of young workers. The essence of this research finding is the meaning of financial behavior is very influenced by financial capability, financial attitude, and income.

The Impact of Capability, Income, and Ethnicity to Financial Position. The financial position of young workers explains the total assets owned at a certain time. Many factors determine the financial position of workers, such as financial capability, income, and ethnicity. But these research results explain the finding that only the ethnicity of young workers who can control financial position because the financial position will only happen in the future and its journey many changes of financial behavior that can change the result of financial position. Other facts are that financial capability and the large income from young workers do not provide a meaningful chance in financial position if it does not support a good financial attitude. It is the same with income, it often changes by a condition where the bigger of income the bigger of expense too. Because of many of the intentions and necessities from each individual and lifestyle in its finance. This research finding explains the importance of ethnicity as one of a determinant factors of financial position, wherein the ethnicity of young workers consisted of some principle of financial management because of culture before. It means that culture or custom has been occurred by workers bring to the advantage behavior in financial position, like a habit of saving or investment by ethnicity or their group.

The result of the research hypothesis test (H12) is the correlation of ethnicity to financial position seems in line with previous research (Ansar et al., 2019), and it can complete the previous research. It is different with the result of other hypotheses tests are financial capability (H2), locus of control (H4), financial knowledge (H6), financial attitude (H8), and income (H10) where it is not in line with previous research (Rehman et al., 2019). These results tend to argue the previous research, and the essence of this finding explains that many factors determine the financial position of young workers in the future, but only consistency of all good financial behavior that can support financial position. It is applied not only in ethnicity adopted by young workers, but also for consistency of financial capability management, locus of control, financial knowledge, financial attitude, and income. Because those factors support truly if it is conducted continually. The problem's fact obtained giving contribution particularly in information about the importance of association in ethnicity and it is consistent with financial behavior to prepare financial position in the future.

The Sensitivity of Financial Position to Financial Behavior of Young Workers. The ordeal of a young worker at the beginning of their career in financial management, it is good for individual or their family. Because of the weak of experience and the low of knowledge, it delivers financial behavior that is not in line with financial position finally. All the factors in financial behavior are financial capability, locus of control, financial knowledge, financial attitude, income, and ethnicity are truly from the previous research can support not only in better financial behavior but also it supports financial position achievement. However, the consistency level of financial behavior implementation often changes, it delivers the occurrence of frauds from the individual practice of financial management and its impacts in unclear financial position. Reviewing from problem facts of financial behavior seems 
clear and important for young workers in noticing and implementing financial behavior consistently if it relates to financial position.

The interesting thing of this research finding is that the testing result $(\mathrm{H} 3)$ is stated financial behavior of young workers does not support financial position in the future. The previous research study explains the importance of financial behavior in supporting financial position (Arianti, 2017). This finding is not in line and tends with arguing the previous research, mention that financial behavior does not always impact in financial position. It seems from another analysis of research studies are stated that the factor impacts financial behavior is the consistency level in the practice of finance (Norden et al., 2014). It means that financial behavior is not running well in supporting financial position if, in the practice, there is no consistency. So, this finding explains the importance of moderation from the consistency level of young workers in the correlation of financial behavior to financial position, because financial position talks about time problem. The time means the achievement of financial position needs the process of financial behavior of young workers. In that process, it needs moderation or support from young workers' consistency in its practice.

Based on research findings, it seems that it occurs vulnerability of financial behavior in financial position if there is no support from young workers' consistency. This vulnerability can be surely anticipated early if the application of financial capability, locus of control, financial knowledge, financial attitude, income, and ethnicity as the support of financial behavior is conducted consistency until it is achieved in financial position. The importance of assessing the vulnerability of financial behavior relates to financial position, so this finding is expected to give important information for stakeholders in evaluating the financial position of the financial behavior process.

\section{CONCLUSIONS}

This study focuses on analyzing the correlation of financial behavior to the financial position of younger workers, through the support of financial capability, locus of control, financial knowledge, financial attitude, income, and ethnicity. Research results explain that young workers who have financial behavior are supported by financial capability, financial attitude and income; it is different from the knowledge that is not able to support positively from financial behavior. In a financial position, it is known that it can be controlled by ethnicity well, it is compared to financial capability and income because it impacts negatively. The financial behavior of young workers is surely directly not impacted well to the financial position in the future. It means that many factors determine like ethnicity or other factors are not examined in this research. This finding is surely useful as additional information in recognizing the financial behavior of young workers in Indonesia, who cannot determine financial position finally.

Reviewing from the fact of research problems, it seems that young workers in Indonesia have the vulnerability of financial position based on the uncertainty of financial behavior so that it needs to be studied other factors that can control financial position. It seems from the correlation which burdensome to financial position, which is financial capability and income, they do not truly provide a good impact on financial position. Financial knowledge is not always controlled by financial behavior from younger workers. 
So, the recommendation of further study is the analysis of other factors that can control the financial position and financial behavior as culture and the norm adopted by young workers.

\section{REFERENCES}

Alamsyah, D. P., Syarifuddin, D., and Mohammed, H. A. A. (2018). Green Customer Behavior on Eco-Friendly Products: Innovation Approach. Jurnal Dinamika Manajemen, 9(2), 159-169.

Ansar, R., Ansar, R., Abd Karim, M. R., Osman, Z., and Fahmi, M. S. (2019). Gender, Educational Qualification and Ethnicity Differences in Personal Financial Management Practices among Generation $\mathrm{Y}$ in Malaysia. Asian Journal of Economics, Business and Accounting, 12(1), 1-7. https://doi.org/10.9734/ajeba/2019/v12i130143

Arianti, B. F. (2017). The Influence of Financial Literacy, Financial Behavior and Income on Investment Decision. European Research Studies Journal, 20(3A), 635-648.

Arslan, Y., Geçti, F., \& Zengin, H. (2013). Examining perceived risk and its influence on attitudes: A study on private label consumers in Turkey. Asian Social Science, 9(4), 158-166. https://doi.org/10.5539/ass.v9n4p158

Banerjee, R., Devereux, M. B., and Lombardo, G. (2016). Self-oriented monetary policy, global financial markets and excess volatility of international capital flows. Journal of International Money and Finance, 68, 275-297. https://doi.org/10.1016/j.jimonfin.2016.02.007.

Barakat, A. (2014). The Impact of Financial Structure, Financial Leverage and Profitability on Industrial Companies Shares Value (Applied Study on a Sample of Saudi Industrial Companies). Research Journal of Finance and Accounting, 5(1), 22222847.

Begley, T. M., and Boyd, D. P. (1987). Psychological Characteristics Associated with Performence in Entrepreneurial Firms and Smaller Businesses. Journal of Business Venturing, 2(1), 79-93. https://doi.org/10.1016/0883-9026(87)90020-6

Chen, M., and Chang, Y. (2013). The Impacts of Human Capital in Enhancing New Venture's Performance. Journal of Knowledge-Based Innovation in China, 5(2), 146168. https://doi.org/10.1108/jkic-06-2013-0011

Croy, G., Gerrans, P., and Speelman, C. (2010). The Role and Relevance of Domain Knowledge, Perceptions of Planning Importance, and Risk Tolerance in Predicting Savings Intentions. Journal of Economic Psychology, 31(6), 860-871. https://doi.org/10.1016/j.joep.2010.06.002

Denny, K. G., and Steiner, H. (2009). External and Internal Factors Influencing Happiness in Elite Collegiate Athletes. Child Psychiatry Hum Dev, 40, 55-72. https://doi.org/10.1007/s10578-008-0111-z.

Di Benedetto, C. A., and Kim, K. H. (2016). Customer Equity and Value Management of Global Brands: Bridging Theory and Practice From Financial and Marketing Perspectives: Introduction to a Journal of Business Research Special Section. Journal of Business Research, 69(9), 3721-3724. https://doi.org/10.1016/j.jbusres.2015.03.048

Dwiastanti, A. (2017). Analysis of Financial Knowledge and Financial Attitude on Locus of Control and Financial Management Behavior. Management and Business Review, 1(1), 1-8. 
Fauceglia, D. (2014). Credit constraints and firm imports of capital goods: Evidence from middle- and low-income countries. International Economics, 140, 1-18. https://doi.org/10.1016/j.inteco.2014.07.002

Gadenne, D., Mia, L., Sands, J., Winata, L., and Hooi, G. (2012). The Influence of Sustainability Performance Management Practices on Organisational Sustainability Performance. Journal of Accounting and Organizational Change, 8(2), 210-235. https://doi.org/10.1108/18325911211230380.

Garg, N., and Singh, S. (2018). Financial literacy among youth. International Journal of Social Economics, 45(1), 173-186. https://doi.org/10.1108/IJSE-11-2016-0303

Ghosh, S. (2014). Risk, capital and financial crisis: Evidence for GCC banks. Borsa Istanbul Review, 14(3), 145-157. https://doi.org/10.1016/j.bir.2014.06.003

Goedde-Menke, M., Langer, T., \& Pfingsten, A. (2014). Impact of the financial crisis on bank run risk - Danger of the days after. Journal of Banking and Finance, 40(1), 522 533. https://doi.org/10.1016/j.jbankfin.2013.11.028

Gomezelj, D. O., and Kušce, I. (2013). The influence of personal and environmental factors on entrepreneurs' performance. Kybernetes, 42(6), 906-927. https://doi.org/10.1108/K-08-2012-0024

Hariyanto, O. I. B., and Alamsyah, D. P. (2019). The Relationship Of Environmental Knowledge And Green Purchase Intention. International Journal of Engineering and Advanced Technology, 8(5), 142-144. https://doi.org/10.35940/ijeat.E1020.0585C19

Henager, R., and Cude, B. J. (2016). Financial Literacy and Long- and Short-Term Financial Behavior in Different Age Groups. Journal of Financial Counseling and Planning, 27(1), 3-19.

Hikmawati, N. K., and Alamsyah, D. P. (2018). The digital company based on competitive strategy. Proceedings of the 3rd International Conference on Informatics and Computing, ICIC 2018, 2001. https://doi.org/10.1109/IAC.2018.8780516

Hong, S., Thong, J. Y. L., \& Tam, K. Y. (2006). Understanding continued information technology usage behavior: A comparison of three models in the context of mobile internet. Decision Support Systems, 42(3), 1819-1834.

Kadoya, Y., and Khan, M. (2017). Explaining Financial Literacy in Japan: New Evidence Using Financial Knowledge, Behavior, and Attitude. SSRN Electronic Journal, February. https://doi.org/10.2139/ssrn.3067799

Keh, H. T., and Xie, Y. (2009). Corporate Reputation and customer Behavioral Intentions: The Roles of Trust, Identification and Commitment. Industrial Marketing Management, 38(7), 732-742. https://doi.org/10.1016/j.indmarman.2008.02.005.

Košak, M., Li, S., Lončarski, I., and Marinč, M. (2015). Quality of bank capital and bank lending behavior during the global financial crisis. International Review of Financial Analysis, 37, 168-183. https://doi.org/10.1016/j.irfa.2014.11.008.

Lee, P. K. C., Lau, A. K. W., and Cheng, T. C. E. (2013). Employee rights protection and financial performance. Journal of Business Research, 66(10), 1861-1869. https://doi.org/10.1016/j.jbusres.2013.02.007

Louati, S., Gargouri Abida, I., and Boujelbene, Y. (2015). Capital Adequacy Implications on Islamic and Non-Islamic Bank's Behavior: Does market power matter? Borsa Istanbul Review, 15(3), 192-204. https://doi.org/10.1016/j.bir.2015.04.001.

Meijers, F., Kuijpers, M., \& Gundy, C. (2013). The relationship between career competencies, career identity, motivation and quality of choice. International Journal 
for Educational and Vocational Guidance, 13(1), 47-66. https://doi.org/10.1007/s10775-012-9237-4.

Meyer, J. P., Stanley, D. J., Herscovitch, L., and Topolnytsky, L. (2002). Affective, continuance, and normative commitment to the organization: A meta-analysis of antecedents, correlates, and consequences. Journal of Vocational Behavior, 61(1), 20 52. https://doi.org/10.1006/jvbe.2001.1842.

Moradi, Z. S., Mirzaeenejad, M., \& Geraeenejad, G. (2016). Effect of Bank-Based or Market-Based Financial Systems on Income Distribution in Selected Countries. Procedia Economics and Finance, 36(16), 510-521. https://doi.org/10.1016/s22125671(16)30067-3

Moreland, K. A. (2018). Seeking Financial Advice and other Desirable Financial Behaviors. Journal of Financial Counseling and Planning, 29(2), 198-207. https://doi.org/10.1891/1052-3073.29.2.198

Murray, K. B., \& Vogel, C. M. (1997). Using a hierarchy-of-effects approach to gauge the effectiveness of corporate social responsibility to generate goodwill toward the firm: Financial versus nonfinancial impacts. Journal of Business Research, 38(2), 141-159. https://doi.org/10.1016/S0148-2963(96)00061-6

Norden, L., Silva Buston, C., \& Wagner, W. (2014). Financial innovation and bank behavior: Evidence from credit markets. Journal of Economic Dynamics and Control, 43, 130-145. https://doi.org/10.1016/j.jedc.2014.01.015

Pension, W., Hastings, J. S., and Mitchell, O. S. (2018). ScholarlyCommons How Financial Literacy and Impatience Shape Retirement Wealth and Investment Behaviors. Wharton Pension Research Council Working Papers, 13.

Rehman, K. U., Akhtar, H., and Shah, S. Z. A. (2019). Framing Effect and Financial Wellbeing: Role of Investment Behaviors as Mediator. Review of Economics and Development Studies, 5(2), 343-354. https://doi.org/10.26710/reads.v5i2.555

Ritchie, B., and Brindley, C. (2009). Cultural determinants of competitiveness within SMEs. Journal of Small Business and Enterprise Development, 12(1), 104-119. https://doi.org/10.1108/14626000510579671

Rizvi, S. A. R., and Arshad, S. (2016). How does Crisis Affect Efficiency? An empirical study of East Asian markets. Borsa Istanbul Review, 16(1), 1-8. https://doi.org/10.1016/j.bir.2015.12.003.

Sawarjuwono, T. (2003). Intellectual Capital: Perlakuan, Pengukuran Dan Pelaporan (Sebuah Library Research). Jurnal Akuntansi Dan Keuangan, 5(1), 35-57. https://doi.org/10.9744/jak.5.1.pp.35-57.

Sawitri, N. N., and Astuty, P. (2018). Market anomalies and effect on returns. European Research Studies Journal, 21(2), 630-649. https://doi.org/10.35808/ersj/1029.

Sawitri, Ni Nyoman. (2019). FDPM After the Global Price Crisis in the Coal Industry. International Journal of Monetary Economics and Finance, 12(1), 59-74. https://doi.org/10.1504/IJMEF.2019.098699.

Sawitri, Ni Nyoman, Ermayanti, D., Farida, U., Junus, D., Baharuddin, Hasmin, Yusriadi, Rachman, E., Jumra, \& Vikaliana, R. (2019). Human Resources Competency, the Use of Information Technology and Internal Accounting Control on Time Procurement of Financial Reporting. Journal of Physics: Conference Series, 1175(1). https://doi.org/10.1088/1742-6596/1175/1/012263

Shiamwama, S. M., Ombayo, J. A., and Mukolwe, M. S. (2014). Internal Factors Affecting 
the Performance of Businesses of Retirees in Kakamega Municipality. International Journal of Business, Humanities and Technology, 4(2), 144-157.

Shivam Dube, V., and Kumar Asthana, P. (2017). A Comparative Study on Financial Literacy of Uttar Pradesh with Central Zone States in India. Journal of Business and Management, 19(10), 22-27. https://doi.org/10.9790/487X-1910032227

Smith, J. R. (2019). The Impact of Race, Ethnicity and Gender on Investor Stock Risk Behavior: Implications for Invest Managers. Journal of Management Policies and Practices, 7(1), 21-42. https://doi.org/10.15640/jmpp.v7n1a3

Subramaniam, A., Al Mamun, A., Yukthamarani Permarupan, P., \& Raihani Binti Zainol, N. (2014). Effects of brand loyalty, image and quality on brand equity: A study among Bank Islam consumers in Kelantan, Malaysia. Asian Social Science, 10(14), 67-73. https://doi.org/10.5539/ass.v10n14p67

Sydler, R., Haefliger, S., \& Pruksa, R. (2014). Measuring intellectual capital with financial figures: Can we predict firm profitability? European Management Journal, 32(2), 244-259. https://doi.org/10.1016/j.emj.2013.01.008

Szendrey, J., and Fiala, L. (2018). "I Think I Can Get Ahead!" Perceived Economic Mobility, Income, and financial Behaviors of Young Adults. Journal of Financial Counseling and Planning, 29(2), 290-303. https://doi.org/10.1891/10523073.29.2.290

Totenhagen, C. J., Wilmarth, M. J., Serido, J., Curran, M. A., and Shim, S. (2019). Pathways from Financial Knowledge to Relationship Satisfaction: The Roles of Financial Behaviors, Perceived Shared Financial Values with the Romantic Partner, and Debt. Journal of Family and Economic Issues, 40(3), 423-437. https://doi.org/10.1007/s10834-019-09611-9

Wahyudi, I., and Sani, G. A. (2014). Interdependence Between Islamic Capital Market and Money Market: Evidence from Indonesia. Borsa Istanbul Review, 14(1), 32-47. https://doi.org/10.1016/j.bir.2013.11.001.

Wang, M., Qiu, C., and Kong, D. (2011). Corporate Social Responsibility, Investor Behaviors, and Stock Market Returns: Evidence from a Natural Experiment in China. Journal of Business Ethics, 101(1), 127-141. https://doi.org/10.1007/s10551-0100713-9.

Wilmarth, M. J. (2017). Financial Behaviors of Military Households: The Role of Financial Literacy and Financial Education. Consumer Interests Annual, 63(1), 1-2.

Wong, R., Ng, P., Bonino, J., Gonzaga, A. M., and Mieczkowski, A. E. (2018). Financial Attitudes and Behaviors of Internal Medicine and Internal Medicine-Pediatrics Residents. Journal of Graduate Medical Education, 10(6), 639-645. https://doi.org/10.4300/JGME-D-18-00015.1

Xiao, J. J., and Porto, N. (2016). Financial Education and Financial Satisfaction: Financial Literacy, Behavior, and Capability as Mediators. International Journal of Bank Marketing. https://doi.org/10.1108/IJBM-01-2016-0009. 